\title{
THE SOURCING OF TECHNOLOGIES, sciendo AN INVESTIGATION IN METAL PROCESSING CLUSTER IN POLAND
}

doi:10.2478/mape-2018-0043

Date of submission of the article to the Editor: 04/2018 Date of acceptance of the article by the Editor: $07 / 2018$

\author{
MAPE 2018, volume 1, issue 1, pp. 339-344
}

\author{
Prof. Wieslaw Urban \\ Elzbieta Krawczyk-Dembicka \\ Bialystok University of Technology, Poland
}

\begin{abstract}
The development of enterprises in the globalised world depends on their development potential and ability to compete with other entities. Of key importance in the field of competitiveness is access to innovative technologies providing a competitive advantage and the ability to cooperate in their acquisition with other entities, e.g. in clusters. The authors attempted to identify the sources of technology and financing options used by companies in the metal processing industry. The studied entities are part of a cluster of national importance, and the adopted research method is based on an interview questionnaire. Studies have shown that most companies buy ready-made solutions and to a lesser extent cooperate in acquiring technology. Noticeable is also a relatively large share of financing investments in new technologies from public funds.
\end{abstract}

Keywords: technology management, metal processing, acquisition, financing, cluster

\section{INTRODUCTION}

Technologies, especially those that are innovative, offer companies a competitive advantage in the market (Coccia, 2017). The source of competitive advantage are also different kinds of business cooperation agreements concluded between companies, R\&D units and business environment units, for example clusters (Greenhalgh, 2014). The combination of these two aspects prompted the authors to formulate questions about the origin of technology in enterprises involved in cluster agreements.

The aim of the study is to examine the methods of acquiring technology by enterprises engaged in the processing of metals belonging to the Metal Processing Cluster. The presented studies also take into account the question of the financing of technology that is inherent in its acquisition. Results presented in this paper are part of large-scale studies related to companies engaged in metal processing.

\section{TECHNOLOGIES AND TECHNOLOGY MANAGEMENT PROCESS}

From an engineering point of view, technology is the process of manufacturing a specific product. It can refer to encoded or concealed knowledge concerning a set of industrial techniques available at a given time (Nieto, 2004), or to the identification of ways to implement certain technological assumptions (Bitzer et al., 2014). Taking into account the different definitions it can be stated that the interpretation of the concept of technology is between science and the production process. Considering access to technology and the ability to use its effects, understood as the capacity to implement innovative solutions, we can conclude that they should become a source of sustained competitive advantage (Song et al., 2013).

Technology can also be seen through the prism of its applications. This allows you to treat it as a system, in which the crucial role is played by: skills and competencies of users (humanware); tools, machinery and equipment used (technoware); available knowledge of the manufacturing processes (infoware); organisational rules and procedures in force in the 
enterprise (orgaware); as well as the entire virtual space (cysnetware), which can be used to control and manage available technologies and the whole enterprise (Sharif, 2012). In practice, these components are closely related, dynamic interactions and defined relationships occur between them, and the added value of the whole technological system for a company is determined by the weakest link. Therefore, it is essential that all elements are equally developed and managed.

One of the first definitions of technology management (TM) states that it combines various engineering and management sciences for the purposes of planning, development and implementation of technological capabilities which enable the implementation of strategic and operational objectives of the organisation (National Research Council U.S., 1987). Research works published in specialist journals also present the definition of technology management as technological asset management (Chanaron and Jolly, 1999) as well as all activities and methods to be taken to make sure that a technology exists in the industry (Bitzer et al., 2014). Rational and effective technology management is an important issue in scientific research units, which are usually the initiators of the creation of new technologies, as well as in companies that modify, implement and operate these technologies. With the increased interest in the analysed subject, the first proposals of models depicting the general framework of the technology management process appeared. The precursor of the research on the construction of the model technology management process was Gregory. His general model identified five main activities related to technology management in enterprises, supplemented with a number of different factors specific to the industries analysed. These include: identification of potential technologies, their selection, acquisition, exploitation and protection of knowledge and experience within the technology (Gregory, 1995). It constituted a reference model for the authors for further research.

Technology plays an important role in the interaction between entities (companies, research and development units), the society and nature, so technological advances can have serious consequences for each of these entities and at the same time depend on their impact (Pelser and Prinsloo, 2014). Therefore, technology management should be based on the recognition of the relationships between individual units and the identification of ways of its rational and efficient use, which creates an analogy to cooperation within clusters.

\section{RESEARCH OBJECT AND METHODOLOGY}

The research process conducted by the authors was based on quantitative studies. Its purpose was to obtain information and explain relationships between them, about poorly recognised phenomena (Dyduch, 2011) partially identified during the previous qualitative studies carried out by the authors (Urban and Krawczyk-Dembicka, 2018). The tool deployed for its implementation was a questionnaire developed based on the results of qualitative studies and verified during expert consultations and pilot studies. The study was conducted using an electronic questionnaire transmitted to respondents through the webankieta.pl service, MPC newsletter, and e-mail and paper surveys distributed by the authors in person and by mail.

One of the objectives pursued by the authors was to identify the phenomena associated with technology management occurring in entities belonging to clusters. A cluster is defined as a geographically close group of companies and associated institutions involved in a particular field, linked by commonalities and complementarities (Porter, 2001). The idea of the functioning of a cluster is based primarily on the cooperation of three groups of stakeholders representing a triad of science-business-administration. Their main aim is to strengthen cooperation and conduct various activities for the development of local entrepreneurship.

The research object were production or production and service enterprises belonging to the Metal Processing Cluster (MPC), operating in the field of metal processing. Therefore, it was necessary to analyse the Cluster population profile to determine the target research sample. The structure of the cluster members with the qualification of the members of the research sample are shown in Table 1. 
Table 1

Characteristics of the selection of the research sample

\begin{tabular}{|c|c|c|}
\hline & $\begin{array}{l}\text { MPC Population } \\
\text { (as of } 30.06 .2017 \text { ) }\end{array}$ & Number of enterprises \\
\hline Total number of enterp & & 74 \\
\hline & consulting & 3 \\
\hline & ICT & 3 \\
\hline Inclualing those & outsourcing & 2 \\
\hline & research institute & 1 \\
\hline & production/production and services & 65 \\
\hline Number of enterprises & at meet the research criteria & 65 \\
\hline & termination of membership in the MPC & 2 \\
\hline abandonment due to: & MPC membership less than 6 months & 3 \\
\hline Number of enterprises & Imitted to the study & 60 \\
\hline
\end{tabular}

Source: own data based on the MPC database.

Finally, the research process included 60 enterprises with the status of active members of the Metal Processing Cluster as at 31.12.2016. In the selected entities of Podlaskie and Mazowieckie Regions the study was conducted in the form of direct interviews with owners, board representatives, executives from the production or technology departments, or designated representatives during visits at the companies. The result of the study is information on the method of managing technology at 54 cluster companies. The paper presents partial results of the research on the method of acquiring technologies and sources of their financing.

\section{RESULTS OF RESEARCH}

\subsection{Sources of technology acquisition}

One of the stages of quantitative research was to identify ways of technology acquisition by companies. Respondents were offered the opportunity to choose multiple answers from presented 6 options as well as to formulate their own answers. The results are shown in Fig. 1.

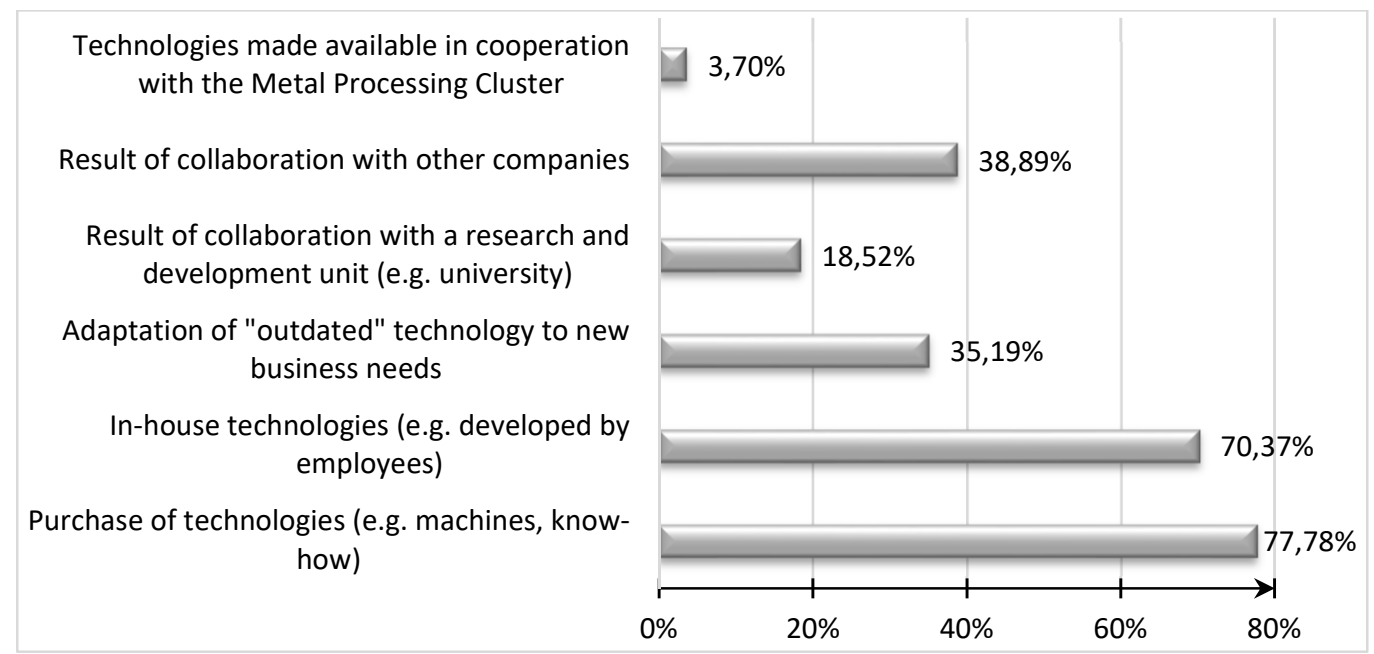

Fig. 1. Sources of technology acquisition by enterprises

Most of respondents (77.78\%) selected the option: Purchase of technologies (e.g. machines, know-how). $70.37 \%$ of the responses selected the variant In-house technologies (e.g. developed by employees). The lowest percentage of respondents (3.70\%) selected the option technology made available in cooperation with the Metal Processing Cluster. The responses strongly suggest individual activities taken by companies. No noticeable results of cooperation between companies and their environment are observed in this matter, but rather orientation to direct technological development of the organisation. 
It should be noted that a relatively small number of respondents selected an answer concerning conducting cooperation with research and development units (e.g. universities) and other companies, which in itself should result from the definition of their operation in the cluster. The situation is similar for direct cooperation in the MPC (provision of technologies). Accordingly, further analysis was based on collected data on the types of technologies used by enterprises - the respondents. Particular attention was paid to the types of technology as declared by the respondents pointing to cooperation in acquiring technology. It turns out that out of approximately 400 types of technology, almost half (192) was mentioned by units that declare cooperation, with 81 technologies resulting from collaboration with research and development units, 155 acquired as a result of collaboration with other companies, and 28 made available in cooperation with the MPC. It should be noted that all respondents indicating cooperation with the MPC also pointed to technology as a result of cooperation with other companies. Cooperation between companies and universities resulted in 44 technologies.

A detailed analysis of the technologies showed that almost $16 \%$ are the so-called preparatory technologies aimed at the appropriate preparation of material for further processing, of which about $13 \%$ are technologies for cutting sheets, tubes, profiles, and the like. The largest share of responses amounting to $34 \%$ comprise machining technology, including turning, milling, drilling, grinding both on conventional and numerically controlled machines. Forming including bending, extrusion or rolling accounted for $8.5 \%$ responses, and surface treatment, including both heat, chemical finishing treatment, was mentioned by approx. $13 \%$ respondents.

Technologies related to assembly/disassembly were mentioned by $17.5 \%$ of respondents, and $3 \%$ responses were included in the category of automation. The distinguishing feature of the technologies indicated by respondents from other sources can be classified as other technologies. Approx. 8\% of enterprises indicated cooperation with research and development units and other businesses, focusing on engineering (machinery, equipment, and technology), development and starting technology components as well as production monitoring and control technologies.

\subsection{Sources of technology financing}

In the next stage of the survey respondents were asked to subjectively identify the main sources of funds for the purchase and development of technology. As in the previous question, respondents were to choose from several optional funding sources, including the ability to add their own answer. The results are presented in Fig. 2.

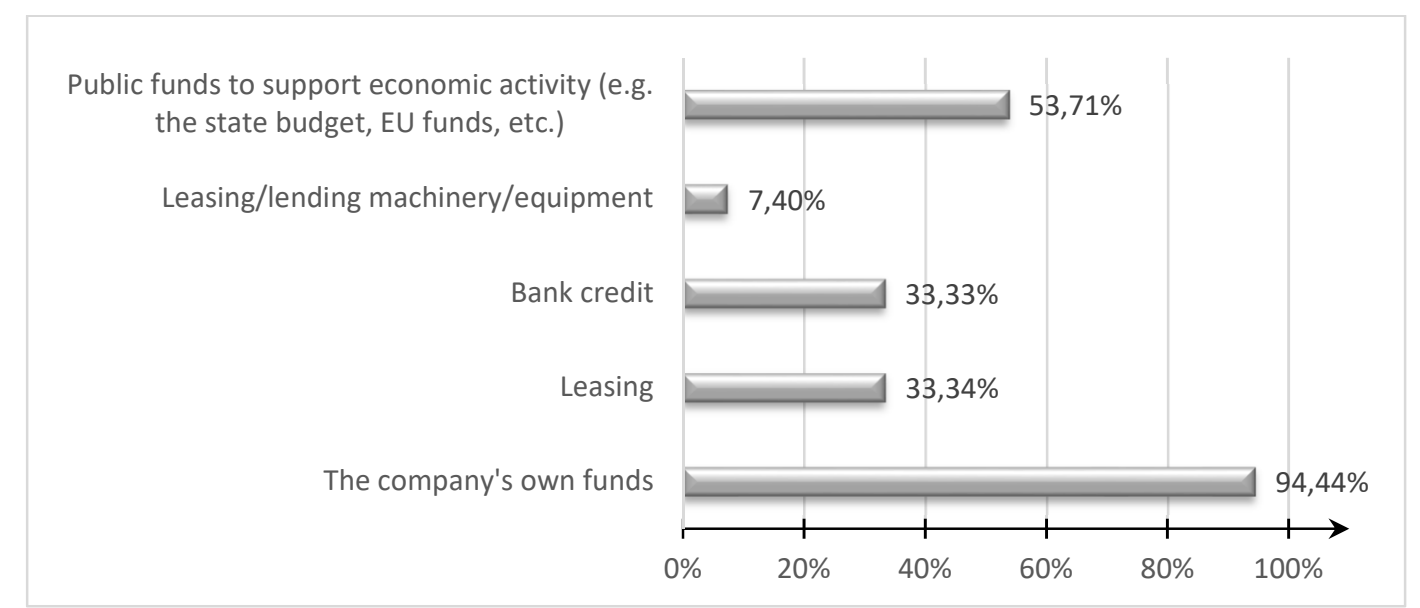

Fig. 2. Sources of technology financing by enterprises

By far the most important source of funding for technology turn out to be the company's own funds. This option is used by $94.44 \%$ of all entities of the Metal Processing Cluster participating in the study. In addition, more than half of the respondents $(53.71 \%)$ declared to be the 
beneficiaries of public funds to support economic activity (e.g. the state budget, EU funds, etc.). The studied companies are the least interested in the possibility of using lease/lending machines/ equipment as a form of financing technology. This form is present in only $7.40 \%$ of cases.

The research previously conducted by the authors shows that companies in the Metal Processing Cluster in 2007-2013 concluded agreements for financing projects related to technologies of a total value of over PLN 260 million, of which the amount of public aid granted amounted to nearly PLN 97 million. The authors found that in the analysed period 30 companies belonging to the cluster implemented a total of 43 different projects related to technological activities (Krawczyk-Dembicka and Urban, 2015). Given the high participation rate of public financing for technology, the ongoing research should be extended to include the analysis of the utilisation of EU funds.

\section{DISCUSSION}

The cluster concept is based on collaboration (cooperation) and competition (coopetition), which is assumed to have a major impact on innovation, and at the same time competitiveness of enterprises. In theory, clusters are the best form of cooperation that enables the combination of science and business (Stocka-Bigaj, 2016). Practice shows, however, that the advantage in this relationship is the simultaneous 'coopetition' which is a combination of cooperation and competition between enterprises, giving them the opportunity to maintain organisational independence (Moczała, 2017). The presented results of studies show that the investigated companies indeed cooperate with other entities in acquiring technology, but on a very small scale. Very often it involves the use of resources of other companies through subcontracting them to prepare batches of material for further processing (e.g. cutting the details to a specific size). By cooperating in the acquisition of technology enterprises at the same time acquire knowledge on the production potential of other entities which they use, limiting the costs associated with the specific technological operations.

In-depth studies in selected enterprises show that, in the case of contact with scientific units, cooperation is limited to the research and development stage or technology testing. In addition, companies use the acquired knowledge to compete with other entities. Thus, cooperation between enterprises and scientific units occurs, but is far from ideal. There are a lot of reasons for this, for instance the formal conditions for the functioning of these entities (Cyran, 2015). In addition, they can be identified as divergent interests and mutual expectations of both parties. This also translates into limited trust and low levels of responses indicating cooperation in the studies described in this paper.

Analysing the sources of financing technology, not without significance is the share of public funds used. Their importance for a company is confirmed by expenditures incurred on innovative activity, relating, among others, to the acquisition of knowledge from external sources, purchase and modernization of technology, infrastructure for technology-related operations or research and development work. According to the CSO data for 2016 expenditures on innovative activity incurred by manufacturing companies in sectors related to wider processing of metals (Chapters 24-28 PCA, 2007) totalled PLN 5.078 million, of which nearly half was spent for the purchase of machinery and equipment $(49.4 \%)$, and a significant share of the funds were various types of aid (Statistics Poland, 2017). The results indicate that the concentration of external funds obtained by cluster enterprises is higher than the average for the group of companies in a given time.

\section{CONCLUSIONS}

An indispensable element in the management of technology in production or production and service companies is the acquisition of technology. Its main source is purchase primarily involving funding the acquisition of new machinery and equipment or specialised knowledge necessary to develop and produce new technology. A significant portion of technology is 
acquired with public funds, for instance from EU projects carried out by enterprises for the purpose of innovation, including the development and modernisation of technology. These activities also translate into support for the company's employees in the work to produce technology within the organization, which determines its unique character and the ability to maintain a competitive advantage in the market. An important source of technology, which is too rarely used by the enterprises involved in the cluster agreement, is cooperation with other entities, research institutions or enterprises. Research has shown that it is limited to work related to research and development of technology as well as its testing. Cooperation between enterprises also involves subcontracting, in this case defined as the use of specific technologies available in the cluster companies to execute work for other companies.

\section{ACKNOWLEDGEMENTS}

The research has been carried out in the framework of the work G/WZ/1/2016 and financed by the National Science Centre (agreement No. 2015/19/N/HS4/02576).

\section{REFERENCES}

Bitzer, M., Vielhaber, M. and Dohr, F. (2014). From Product Development to Technology Development, In: Proc. 24th CIRP Design Conference, Giovanni Moroni and Tullio Tolio (ed.), Procedia CIRP $21,247-251$.

Chanaron, J.J. and Jolly, D. (1999). Technological management: expanding the perspective of management of technology. Management Decision, 37(8), pp. 613-621.

Coccia, M. (2017). Sources of technological innovation: Radical and incremental innovation problemdriven to support competitive advantage of firms. Technology Analysis \& Strategic Management, 29(9), pp. 1048-1061.

Cyran, K. (2015). Barriers of cooperation of business sphere with scientific Units from the perspective of small and medium enterprises. Modern Management Review, XX, 22(3/2015), pp. 23-33, (in: Polish).

Dyduch, W. (2011). Ilościowe badanie i operacjonalizacja zjawisk w naukach o zarządzaniu, In: W. Czakon, ed., Podstawy metodologii badań w naukach o zarządzaniu, Warsaw: Wolters Kluwer Polska sp. z o.o., (in: Polish).

Greenhalgh, B., ed., (2014). Internacjonalizacja klastrów. Warsaw: Polska Agencja Rozwoju Przedsiębiorczości, (in: Polish).

Gregory, M.J. (1995). Technology management: a process approach. Proceedings of the Institution of Mechanical Engineers, 209, pp. 347-356.

Krawczyk-Dembicka, E. and Urban, W. (2015). Technology management process - models review and gasps identification, In: AVADA 2015: Drivers for Progress in the Global Society: Abstracts' Book, Pärnu, pp. 19-20.

Moczała, A. (2017). Co-operation and co-opetition in the innovation process. Zarządzanie Przedsiębiorstwem, 4, pp. 36-46, (in: Polish).

Nieto, M. (2004). Basic propositions for the study of the technological innovation process in the firm. European Journal of Innovation Management, 7(4), pp. 314-324.

Pelser, T.G. and Prinsloo, J.J. (2014). Technology management and the link with technology strategy and company performance. Journal of Global Business and Technology, 10(2), pp. 1-12.

Porter, M.E. (2001). Porter o konkurencji. Warsaw: Polskie Wydawnictwo Ekonomiczne, (in: Polish).

Sharif, M.N. (2012). Technology innovation governance for winding the future. Technological Forecasting and Social Change, 79, pp. 595-604.

Song, M., Zhao, Y.L. and Di Benedetto, C.A. (2013). Do perceived pioneering advantages lead to firstmover decisions? Journal of Business Research, 66(8), pp. 1143-1152.

Statistics Poland, (2017). Innovative activity of enterprises in the years 2014-2016. Warsaw, Szczecin: Statistical Office in Szczecin. Available at: http://stat.gov.pl/obszary-tematyczne/nauka-itechnika-spoleczenstwo-informacyjne/ [Accessed 20 May 2018].

Stocka-Bigaj, M. (2016). Clusters as a factor of enterprise competition in Poland in the times of economic crisis. Zeszyty Naukowe Polskiego Towarzystwa Ekonomicznego w Zielonej Górze, 5, pp. 184194, (in: Polish).

Task Force on Management of Technology; National Research Council (U.S.) Cross-Disciplinary Engineering Research Committee; National Research Council (U.S.). (1987). Manufacturing Studies Board: Management of Technology: the hidden competitive advantage. National Academy Press Washington, p. 9.

Urban, W. and Krawczyk-Dembicka, E. (2018). Case Studies of the Process-Oriented Approach to Technology Management. In: A. Hamrol, ed., O. Ciszak, ed., Legutko S., ed. and Jurczyk M., ed., Advances in Manufacturing, Cham: Springer International Publishing, pp. 259-268. 